\title{
FROM SPACES OF EXCEPTION TO 'CAMPSCAPES': PALESTINIAN REFUGEE CAMPS AND INFORMAL SETTLEMENTS IN BEIRUT
}

\section{$\underline{\text { Abstract }}$}

The recent literature on the refugee condition and spaces has heavily drawn on Agamben's reflection

on 'bare life' and the 'camp'. As refugees are cast out the normal juridical order, their lives are confined to refugee camps, biopolitical spaces that allow for the separation of the alien from the nation. But is the camp the only spatial device that separates qualified and expendable lives? What happens when the space of the camp overlaps with the space of the city? Taking the Palestinian refugee camp of Shatila in Beirut as a case, this study problematises the utilisation of legal prisms and clear-cut distinctions for the understanding of the production of bare life and spaces of exception. Isolated at the time of its establishment, Shatila is today part of the so-called 'misery belt'. Physical continuities are also reflected by the distribution of the population as both Palestinians and non-Palestinians, including Lebanese, live in Shatila and the surrounding informal settlements. As physical and symbolic boundaries separating the refugee and the citizen blur, I argue that the exception is not only produced through law and its suspension. While legal exceptions place the Palestinians outside the juridical order, other exclusions run along sectarian and socio-economic lines cutting through the Lebanese body. As Shatila and the informal settlements are entangled, a new 
spatial model of analysis defined as the 'campscape' is proposed. Once the exception leaks out of the space of the camp, the campscape becomes the threshold where the refugee, the citizen and other outcasts meet.

\section{$\underline{\text { Keywords }}$}

space of exception; refugee camp; informal settlements; Palestinian refugees; Lebanon

\section{$\underline{\text { Abbreviated title }}$}

FROM SPACES OF EXCEPTION TO 'CAMPSCAPES' 


\section{FROM SPACES OF EXCEPTION TO 'CAMPSCAPES’:}

\section{PALESTINIAN REFUGEE CAMPS AND INFORMAL SETTLEMENTS IN BEIRUT}

One of the essential characteristics of modern biopolitics [...] is its constant need to redefine the threshold in life that distinguishes and separates what is inside from what is outside. [...] And when natural life is wholly included in the polis - and this much has, by now, already happened - these thresholds pass, as we will see, beyond the dark boundaries separating life from death in order to identify a new living dead man, a new sacred man.

(Agamben, 1998:131)

\section{Introduction}

As a result of the first Arab-Israeli conflict between 1947 and 1948, more than 750,000 Palestinians were expelled or fled from their homes and villages (UNRWA, 2014a). About 100,000 found refuge in Lebanon where, after an initial welcome, they have faced multifaceted forms of marginalisation. This is due to the peculiar sectarian character of Lebanese politics. It registers the highest percentage of Christians among all Middle Eastern countries and a power-sharing formula between different sects characterises political life. The presence of a mostly Muslim refugee community constituting about ten percent of the total population in Lebanon, therefore, has always been perceived as a threat to the country's delicate political order and stability (Haddad, 2000: 30). 
The Lebanese government's concerns over its population are manifested institutionally through the issue of laws, decrees and orders that prevent the Palestinians from enjoying the most basic rights such as the right to work and access to educational and health services; and spatially through the establishment of refugee camps. As laws, decrees and orders dictate the conceptual separation of the Palestinian refugee from the Lebanese citizen, refugee camps complete such distinction geographically preventing the Palestinians' integration.

As philosopher Giorgio Agamben (1998) would put it, the production of refugees' 'bare life' - a life stripped of any right and value - and its spatialisation through the establishment of camps is not new to our times. Drawing a controversial parallel between the Nazi concentration camps and temporary structures such as refugee camps and detention centres, Agamben urges us to recognise the logic of exception pervading our societies. Conceived as 'a piece of land that is placed outside the normal juridical order', the camp has become the 'hidden matrix' of the modern political space and the technique of government to exclude, enclose and/or even eliminate those who threaten the security of the state (Agamben, 1998: 170).

Recognising the invaluable contribution of Agamben in the understanding of biopolitics and exception in situations of refugeeness, this paper aims to further the reflection on the ways in which biopolitics may operate today and the ways in which the exception may be conceived and spatialised.

While Agamben's conceptualisation of the camp grounds this study, the spatialisation of exclusion is more nuanced because, of the 444,480 Palestinian refugees registered with the United Nations Relief and Works Agency (UNRWA) in Lebanon, only 241,322 live in the twelve official refugee camps (UNRWA, 2014b). These figures are also reflected globally as the United Nations High Commissioner for Refugees (UNHCR) estimates that often refugees live in urban areas and that only one third of the 10.4 million refugees worldwide, excluding the Palestinians, live in refugee camps (UNHCR, 2013: 6, 8). It seems that the refugee population is more dispersed than sociologists or biopolitics theorists would expect them to be. Life in the camp for refugees does not constitute the norm. 
In investigating the refugee condition and spaces, this paper focuses on Shatila refugee camp. Established far from the city centre in 1949, Shatila is now part of the urban texture of metropolitan Beirut and the city's 'misery belt', an axis of low-income and informal settlements surrounding Beirut's city centre. This urban condition is shared by other Palestinian camps in Lebanon and the Middle East and, as I suggest below, this complicates their construction as 'exceptional' spaces. Additionally, the high presence of non-Palestinians in Shatila, which includes Lebanese, Syrians, Turks, Egyptians, and Bangladeshis, problematises the clear-cut production and separation of bare and qualified lives, respectively and allegedly embodied by the figures of the refugee and the citizen. In light of the entanglement of the camp with the city and the lives of different outcasts, is it entirely true that the camp and the camp only could be the paradigmatic spatial device that divides the life worth living from the expendable life? What happens when the space of the camp begins overlapping with the space of the city? In contrast with the literature that looks at the camp in its isolation, this paper investigates the camp's relation to the city and its informal settlements. While I do not suggest that the camp is fully integrated into the dynamics of the city, I argue that the camp inhabits an expanded version of the exception which includes non-refugees too.

This paper, part of a broader research project on Palestinian refugees' lives and spaces in Lebanon, is based on a combination of different qualitative methods. Fieldwork was undertaken between October 2008 and January 2009 and included ethnographic practices of observation and more than twenty semi-structured and in-depth interviews with Palestinian refugees and Lebanese citizens living in Shatila camp and the surrounding areas. The research also included archive and desktop research on the condition and status of refugee camps and informal settlements in Beirut. These literatures are pivotal for the understanding of the population that inhabits Beirut's 'misery belt' and the development of informal settlements in the periphery and proximity of refugee camps. While research in the field started with a focus on the refugee camp only and the lives of the Palestinian refugees there, the field challenged research questions and assumptions. Encounters in the camp with Palestinians and Lebanese as well as the difficulty in identifying the limits of the camp revealed 
blurred physical and conceptual boundaries that allegedly would separate citizens and non-citizens, and here the focus is on these blurred boundaries.

Examining the complexities of the exception produced in Lebanon, this paper is divided into three sections. The first section provides the theoretical background. It explores the concepts of bare life and the space of exception and their applicability in situations of refugeeness with a glimpse into Palestinian refugees' lives and spaces in Lebanon. The second part investigates the kind of biopolitics produced in Lebanon and examines the treatment of Palestinian refugees as well as Lebanese citizens. In the third section, the paper explores the exception spatially. From the establishment of Shatila refugee camp to the uncontrolled urbanisation of the 1950 s and $1960 \mathrm{~s}$, it discusses the production of Beirut's 'misery belt' and the merging of refugee spaces and informal urban settlements

In these sections, I argue that bare life is not only produced in legal terms as Palestinians are excluded from the benefits of citizenship, but is also rendered such through social and economic discourses and practices cutting through the Lebanese population and separating Lebanese lives that are worth living from those deserving the sovereign's abandonment. While Agamben's contribution to the understanding of the interactions between law, politics and life is indisputable, a partial disengagement from law is crucial if we are to explain the physical and symbolic proximity of refugees and citizens. Embracing processes and transformation occurring beyond the realm of law, Foucault (1997: 300) argued that:

If you try to analyse power not on the basis of freedom, strategies and governmentality, but on the basis of the political institution, you can only conceive of the subject as a subject of law. One then has a subject who has or does not have rights, who has had these rights either granted or removed by the institution of political society; and all this brings us back to a legal concept of the subject. 
Legal distinctions alone cannot fully capture the complexities of life, forms of lives and their spatialisations. While the paper draws heavily on the theory of exception and exclusion, the discussion of biopolitics and the ways in which it operates is also inspired by Foucault's understanding of biopower and the abandonment of models of analysis exclusively based on law and rights (Foucault, 1998, 2003).

To describe the increasing propinquity of the refugees and some citizens, as well as the impossibility of identifying the space of exception solely within the camp boundaries, such blurred distinctions are conceptualised through a new spatial model of exception. Borrowing from Arjun Appadurai's (1996) understanding of modernity that focuses on continuities, the paper argues that bare life and the exception exceed the boundaries of the refugees' bodies and spaces to include the citizens and other outcasts in the formation of what I term the 'campscape'. The case of Shatila and other Palestinian refugee camps in the Middle East show how the model of the camp as proposed by Agamben cannot capture the complexities of the exception and its spatialities.

While refugee spaces are established as temporary measures to prevent integration and to wait for a solution to refugeeness to be found, they are increasingly becoming permanent solutions. Born as spaces that freeze their inhabitants' status and condition, camps turn their temporariness into a 'transient permanency' in which camps may evolve over time, expand or even turn into city-like structures and in which life continues and where refugees and inhabitants reproduce their own normality (Agier, 2002, 2011).

\section{From concentration camps to Shatila refugee camp}

Although geographers have used the concept of biopolitics and its spatialisation in different ways and have been influenced by certain thinkers over others (see Coleman and Grove, 2009), Agamben's theory of exception has greatly influenced the ways in which we look at refugees, immigrants and those placed outside the national political community. It was Michel Foucault who first coined the 
term biopolitics to indicate the inclusion of life in the mechanism of power. For him, biopolitics emerged in the seventeenth century when power's concerns began focusing on the population as a whole, conceived as a political, scientific and biological problem (Foucault, 1998, 2003).

Though deeply indebted to Foucault, Agamben's $(1998,2005)$ take on biopolitics differs in the ways in which power is conceptualised. According to Agamben, biopolitics is not a modern phenomenon, as ever since ancient times the main task of the sovereign has been to produce and separate lives worth living - thus included in the normal juridical order and protected - from bare lives - excluded from the juridical order at the point of being killable with impunity. The distinction between the life worth living and the one deserving abandonment is also reproduced spatially. As the norm is never applicable to 'chaos', the 'where' of its applicability must be localised (Minca, 2007). If historically the city has constituted the paradigmatic space of social and political life, its walls have marked the beginning of civilisation, where political space was divided from the state of nature (Diken, 2005). The erection of the fence, therefore, is the originary gesture that creates both order and disorder, law and its suspension, political space and space where the normal juridical order does not apply (Schmitt, 2003).

Although, according to Agamben, biopolitics has a long history, the overarching development of the modern era is that bare life has penetrated the political space and that the space of exception, where bare life is hidden and confined, has come to coincide with the qualified space of the polis. In particular, in the context of the nation-state and with discourses on race and racial purity, newborn western democracies have turned foreigners into 'biological threats' to the national community and space. The advent of 'state racism' found its most brutal form in Nazi Germany as, in its effort to protect the Germanic race, it systematically segregated and even eliminated all categories of people that it deemed unsuitable for integration into the national political body (Agamben, 1998; Foucault, 2003). 
The penetration of bare life into political space is today represented by the presence of immigrants, refugees and asylum seekers who 'spoil' and 'contaminate' the harmony of the nation. As the trinity of localisation (Territory), order (State) and birth (the Nation) can no longer be held together without disruptions, new geographies of exception become the hidden matrix of modern political space. While they regulate and order our societies, refugee camps and detention centres work as purifying filters of the nation (Bigo, 2007; Diken and Laustsen, 2005; Perera, 2002; Rajaram, 2007; Rajaram and Grundy-Warr, 2004).

As refugee camps are "a form of geopolitical humanitarianism that has as its "core business" the preservation of the value of the nation-state' (Lui, 2002), it is not surprising that this humanitarian intervention and solution was also applied in 1948 when more than 750,000 Palestinians became refugees. In Lebanon, where they encountered the harshest conditions because of the particular sectarian system, refugee camps were soon established. With the excuse of gathering the refugees to provide humanitarian assistance, Palestinians were forced to move to the camps, either by the Lebanese authorities or by circumstances dictated by their precarious livelihoods (Peteet, 2005).

While the Lebanese authorities wished to establish camps far from inhabited areas to prevent the integration of the Palestinians and reduce the chances of interactions with the Lebanese, most of the official camps and locations have been dictated by refugees' early settlements and needs such as proximity to job opportunities. Shatila refugee camp was established in 1949 by refugees themselves as they decided where to settle by securing the land in an empty spot not far from Beirut. Only later did the International Committee of the Red Cross officialise the status of the camp (Sayigh, 1994). As Ahmad, a Palestinian refugee in his 80 s whom I met in Shatila during my fieldwork, said:

[...] In Adloun I worked in the field, I didn't like this kind of job, so we moved to Beirut. There were some refugees in the park. We asked about the owner of this empty spot, his name was Abdallah Saleh, but the person in charge was Basha Shatila [...] People staying in the park, like Abu Kamal and Abu Zaarour, went to him and asked for his permission. They 
complained about their bad situation. He told them that the owners of the land are Saad's family, they live in Brazil... But since he is the responsible, and the representative of the landlord, he allowed them to move there (Interview with Ahmad, December 2008).

Although refugees managed to dictate the location of their camp, life in Shatila and other refugee camps in Lebanon was not easy. In the first twenty years of their residency in Lebanon, the Palestinians experienced the harshest oppression. To better monitor the refugees' activities and guarantee their isolation, offices of police and intelligence services were placed in the camps and refugees became the objects of intimidation, arbitrary abuses and even torture (Sayigh, 1994).

If at the beginning refugees in Lebanon met violence and control at the hands of the Lebanese authorities, things changed dramatically in 1969 when the Lebanese government and the Palestine Liberation Organisation (PLO) signed the Cairo Agreements. These accords gave the Palestinians the right to train in Lebanon for the liberation of their homeland. But most important of all, they permitted the Palestinians to self-administer their spaces. While in the early years of their presence in Lebanon Palestinians were prevented from expanding their camps and building what would have created a sense of permanency, from 1969 on refugees began constructing with concrete two or more storey buildings and expanding the camp beyond its boundaries. This is the moment at which the camp started meeting the informal settlements and the ever expanding 'misery belt'.

\section{Producing bare life in Lebanon}

According to informal statistics collected at the UNRWA office in Beirut during fieldwork, about thirty percent of Shatila's population is non-Palestinian. The presence of Lebanese and other foreigners such as Syrians, Egyptians and Bangladeshis in the camp urges a reflection on the kind of biopolitics that is at stake in Lebanon. If we follow Agamben's understanding of biopolitics - that is, the production of bare life as a result of a legal abandonment - at first glance the Palestinian refugees, because of their statelessness, are the only group excluded from the protection of the state. Yet, this 
understanding does not seem to capture the complexity of the exception and exclusion as applied in Lebanon.

With regard to the Palestinians, not all of them were treated the same way. Not all of them were forced to live in refugee camps and were prevented integration into Lebanese society and economy. The sectarian character of Lebanese politics played a significant role in the ways in which Palestinians were treated. According to the 1932 census, the largest community within Lebanon was the Maronite Christian sect, followed by Sunni Muslims and Shi'a Muslims. This meant that key positions, such as the Presidency of the Republic, have since then been granted to Maronites while the offices of Prime Minister and Speaker of Parliament have been given to Sunnis and Shi'ites respectively. The maintenance of the demographic, and therefore political, status quo led to a well-planned fragmentation of the Palestinian body. Along with national and non-national distinctions, sectarian and class patterns have also guided spatial, social and political distinctions. Profits in economic terms and advantages in the political arena were the Lebanese government's concerns in the implementation of policies that included some Palestinians and excluded others.

The Palestinian middle and upper classes have never known life in the camps. The most well-to-do Palestinians, especially the Christians, were allowed to settle in the cities and integrate into Lebanese society while their capital was absorbed and invested in new businesses and companies. Due to their money and wealth, upper class Palestinians were welcomed as they offered the prospect of an invaluable economic and financial contribution to the Lebanese economy. The confessionalisation of the Palestinian body became even more obvious as between the 1950 s and 1970 s some 28,000 Christian Palestinians were encouraged to obtain Lebanese citizenship in the government's attempt to counterbalance the rampant growth of the Muslim population (El-Natour, 1993: 42).

While national belonging was a primary factor that separated the Palestinians from the Lebanese, it was not an exclusive one. Confessional and financial patterns were also arbitrarily applied in order to divide those worth protecting and integrating from those whose exclusion was essential. If we 
extend the concept of biopolitics, distancing its definition from a purely legal understanding to include other forms of abandonment and exclusion, the Palestinian refugees in Lebanon are not the only 'banned'. Fawaz and Peillen (2002: 4) reported that since the end of the civil war more than twenty-five percent of the Lebanese population 'lives below the poverty line', while '25.8 percent of individuals [...] in Beirut earn less than US\$106/month'. Though Lebanese poverty has been aggravated by the massive displacement and destruction caused by the civil war (1975-1990), looking at the root of the Lebanese citizenship illustrates how economic and sectarian concerns have always had the upper hand in the decision-making process that shaped Lebanon as a state and its population.

The 1932 census, which played a crucial role in the determination of Lebanese politics, has always been highly contested because of its distinction of who could be considered a Lebanese citizen and who had to be excluded. Maktabi (1999) questions the ways in which the data in the census were obtained and, in doing so, illustrates inconsistencies that ultimately determined citizenship or lack thereof. Differences in the selection of criteria between the first census of 1921 and the one of 1932 changed the ways in which citizenship could be granted, and along with it, the right to vote. While the 1921 statistics had only an administrative purpose, Resolution 2825 issued on 30 August 1924 determined that all the former Ottoman subjects residing in Greater Lebanon would, on that date, become Lebanese citizens. Hence, presence on territory at that time was the essential requirement.

However, these provisions changed in 1932 when a new census recounted the Lebanese residing in Lebanon and also included the emigrant population that was not considered previously. On the one hand, many residents in Lebanon, primarily Muslims, were denied citizenship after the 1932 census because they lacked proper documentation that proved their residence there for generations. On the other hand, priority was granted to Christians, whether they were emigrants living elsewhere or newly arrived such as Armenians fleeing persecution in Turkey. Christian communities were definitively favoured at the expenses of their Muslim counterparts. For instance, Kurdish refugees, 
mostly Muslim, were never granted the same rights as the Armenians, Chaldeans or members of other Christian sects that settled in Lebanon. These 'adjustments' were aimed at maintaining the Christian demographic majority and, as a consequence, political supremacy (Maktabi, 1999).

Yet, as distinctions are never drawn once and for all, boundaries of inclusion and exclusion are constantly produced. What once was included formally - those having acquired Lebanese citizenship by virtue of birth - could be excluded informally later on through acts of political and economic abandonment. A complex redefinition of the threshold separating the one protected by the sovereign and the one abandoned must therefore be reworked on economic, political and social lines. While officially Lebanese nationals are protected by their state, unofficially the sectarian and neoliberal system of the country (see below) redraws lines of inclusion and exclusion.

It is no wonder that refugee populations and the more marginalised among the Lebanese might end up living in and sharing the same spaces. In our encounter in Sabra, Fadi, a Lebanese man married to a Palestinian, told me his story of coexistence and solidarity with the Palestinians as he was born and raised in Shatila (Interview with Fadi, December 2008). His account shows how difficult and problematic it is to draw the boundary between him and his neighbours. This is not only because he married a Palestinian and even joined the resistance in Fatah ranks, but also because being Palestinian or Lebanese seemed not to make much difference. Not in social and economic terms, as some Lebanese and Palestinians share the same condition. Not in the political value of his family's and his own life as he lost his father during the massacre of Sabra and Shatila in 1982 when Christian militias attacked the refugee camp and its surroundings as revenge for the assassination of president Bachir Gemayel for which Palestinian factions were suspected of being responsible. Sharing the same spaces and conditions blurred national boundaries that allegedly separate the refugee from the citizen. In such circumstances, the lives of Lebanese who were living side by side with the Palestinians became expendable and killable too. 


\section{The camp meets the city: The production of Beirut's 'misery belt'}

It is often argued that the Lebanese civil war (1975-1990) was the product of sectarian tensions between the different religious communities in Lebanon. What is less often argued is that sectarian tensions were the product of socio-economic injustices and exclusions that date back to the period of the French Mandate (1920-1943) (Traboulsi, 2007). While the seeds of Lebanon's sectarian, economic and political structure were planted in the period of early Ottoman domination, when different sects confronted each other over political and socio-economic privileges, the institutionalisation of the sectarian system came with the French domination and the arbitrary creation of Greater Lebanon in 1921. To the rich province of Mount Lebanon, mainly inhabited by Druze and Christian sects, the provinces of the South, the North, the Bekaa Valley and the coastal cities of Beirut, Saida, Tyre and Tripoli mainly inhabited by Muslims were annexed. Inequalities were exacerbated as taxation coming from the newly annexed territories was mainly spent and invested on Mount Lebanon. Under the pressure of the French, banking and trading soon flourished at the expense of the agricultural and industrial sectors (Traboulsi, 2007).

With the formal independence of the country in 1943, the Lebanese presidency, held by the Maronite community, became 'the main pole of attraction for the country's dominant economic interests' as the main economic activities in the countries were controlled by some thirty families pivoting around the figure of Bechara Al-Khouri, the first Lebanese president (Traboulsi, 2007: 115). As Christian members of this oligarchy controlled banks, agricultural and industrial production and the whole service system comprising transport, water and electricity companies, Muslims, and in particular Shi'ites, were left in an inferior position.

While Lebanon experienced unprecedented economic growth in the immediate post-independence period, the benefits were not distributed equally as profits tended to be concentrated in Beirut and in the area of Mount Lebanon, exacerbating sectarian inequalities and divisions. The development of Beirut as the financial centre of the Middle East that started under the auspices of the French was 
continuing at the expense of the countryside. While Beirut was developed through plans aimed at improving its infrastructure, its road and transportation systems, and its real estate and construction sectors, little investment was directed toward the agricultural sector and the Lebanese in rural areas were left with no services. In the 1960s the south still had no running water, electricity, hospitals or schools as even basic services were a luxury for the few. The country's liberal economic system reserved just 0.7 percent of the state budget for the South which was inhabited by twenty percent of the country's population (Sayigh, 1994: 162).

This was the climate when, at the beginning of the 1950s, waves of Lebanese left their homes in search of fortune and better conditions in Beirut. The urbanisation of the country was of such explosive and uncontrollable proportions that migrants began pouring into the periphery of the capital populated by former Armenian refugee camps and neighbourhoods, as well as Palestinian refugee camps. What later came to be called Beirut's 'misery belt' seemed to follow an axis drawn around the capital along a line starting in the eastern part of city from the former Armenian camp of Medawar in Quarantina, proceeding towards the Palestinian camps of Tell El-Zaatar, Jisr El-Basha and Dbayeh and stretching towards the western part of Beirut to include the camps of Shatila, Mar Elias and Burj El-Barajneh (Salibi, 1976). The explosion of informal settlements made villages around the capital become the natural extension of its centre while refugee camps, not isolated any longer, began touching the city. As informal settlement mushroomed, the 'misery belt' became the threshold where the camp and the city met. So while biopolitical imaginations may depict the camp as an isolated space, well demarcated and impermeable, this does not reflect the reality on the ground.

The concentration of informal settlements in areas with a high presence and density of refugee communities is not limited to the period following the 1950s. Beirut refugee camps and neighbourhoods had welcomed rural migrants on other occasions too as Armenian and Syriac camps established in the 1920s in the eastern part of the city became the first poles of attraction for those 
in need of cheap accommodation (Fawaz and Peillen, 2002). As Armenians began abandoning their camps, spaces were filled by Lebanese leaving the countryside and foreign migrants such as Kurds and Syrians. If the Armenian refugee camps provided shelter for other kinds of migrants, so did the Palestinian refugee camps of the capital as non-Palestinians settled within their boundaries or in their proximity.

Especially after the Cairo Agreement (1969) that allowed the Palestinians to self-administer the camp (see above), the lands around Shatila began being populated by new settlers that included Palestinians and Lebanese citizens. Although, officially, refugee camps cannot expand, the quarters of Sabra and Hay Gharbeh, respectively north and west of the camp, became the natural extensions of Shatila (Clerc-Huybrechts, 2008). The presence of services such as health care and job opportunities, provided by the Palestinian organisations and open to anyone in need, also contributed to the growth of the area and informal settlements.

As Fawaz and Peillen (2002) suggest, the north-eastern part of the 'misery belt' attracted those in search of jobs in the industrial sector while the western side constituted an appealing destination as the construction sector was developing around major projects such as the Sport City Stadium, Beirut International Airport and the Gulf Club. Urban planning focused on the development of luxurious residential areas, so that, on the eve of the civil war, some 40,000 to 50,000 high standard apartments in the whole of Beirut were left empty while the demand for low-cost housing was never satisfied (Clerc-Huybrechts, 2008: 42; Trabousli, 2007: 160). By the early 1970s the inhabitants of the shantytowns were mostly, although not exclusively, Shi'ites who were economically and socially marginalised. Forced to share the same neglected and forgotten urban spaces because of overcrowding, poor sanitation and health conditions, and a scarcity of services such as water and electricity, poor Lebanese and the Palestinians also shared the feeling of abandonment and vulnerability. 
As one of the reasons for the breakout of the civil conflict was the extreme deprivation of certain layers of society, a meticulous 'sectarianisation' of reconstruction projects was also applied in the 1980s. Maronite enclaves were privileged over the overcrowded southern suburbs of the city hosting mainly Muslims, and over the south of the country whose agricultural production and means of livelihood were destroyed by repeated Israeli attacks and invasions. In metropolitan Beirut, the Lebanese government allocated LL100 million for a new sewage system in the region of North Metn housing some 150,000 people while only LL30million was spent in the southern suburbs with some 700,000 inhabitants (Sayigh, 1994: 135).

These polices of exclusion in reconstruction were continued after the end of the civil war. While major efforts were put in the heavily contested reconstruction of the financial district to attract foreign investment by providing an economically stable facade for the country (Gavin, 1998), the rehabilitation of the suburbs and its inhabitants has yet to be completed. Low-cost housing has never been provided and the displaced continue solving their accommodation needs by expanding informal settlements (Salam, 1998).

In Lebanon, biopolitical concerns do not run along national or citizenship tracks only. If primary distinctions based on law, rights and citizenship separate the Palestinians from the Lebanese, secondary distinctions cut through the very Palestinian and Lebanese bodies. While the camp is the spatial device that contains the threat and separates the refugee from the citizen, this technology of power may lose its effectiveness and function over time. As sectarian, political and economic interests produce other outcasts, refugee camps and informal settlements become thresholds where the refugee meets the citizen.

\section{The production of the 'campscape'}

Palestinian refugees are not the only 'bare lives' in Lebanon. Spatially this is manifested through the blurring of boundaries separating Shatila from its outside. In place of clear-cut fences Beirut is 
characterised by 'disjunctive orders' that divide spaces and peoples. Rather than looking at the camp, it may be more appropriate to focus on the 'campscape'. As Arjun Appadurai (1996: 33) suggests:

[t]he suffix-scape allows us to point to the fluid, irregular shapes [...] These terms with the common suffix -scape also indicate that these are not objectively given relations that look the same from every angle of vision but, rather, that they are deeply perspectival constructs, inflected by the historical, linguistic, and political situatedness of different sorts of actors: nation-states, multinationals, diasporic communities, as well as subnational groupings and movements (whether religious, political, or economic), and even intimate face-to-face groups, such as villages, neighbourhoods, and families.

The suffix -scape gives the idea of fluidity, of something elastic. It indicates dispersal and non-static boundaries. The notion of campscape seems to better render the image of what is the refugee camp today in its relation with its surroundings as the exception has transcended the camp's shape.

Today the difference between Shatila and its outside is barely perceptible as many Palestinians also live outside Shatila's official boundaries. No fence or wall surrounds Shatila and, as it appears today, the camp has only one net on its northern side with multiple points of access. The rest of the camp is open and boundaries are represented by streets that are wider than the narrow alleys within it. It is precisely this openness and lack of control that facilitated the increase of the camp's population.

The camp is not an exclusive Palestinian space. Some Lebanese have been living there because of intermarriages as it emerged during interviews and informal encounters. People who moved to the camp in the last twenty years are internally displaced by the civil war (both Palestinians and Lebanese), and Lebanese citizens and other migrants who moved to Beirut in search of better opportunities and who found accommodation in the camp cheaper than other areas of the city. Out of a population of about 12,000 to 13,000 people, unofficial UNRWA statistics, collected during fieldwork, estimate that some thirty percent of the camp population is non-Palestinian including Lebanese, Syrians, Egyptians and other Arab and non-Arab nationalities. 
If before the civil war, members of one family used to occupy an entire building, today the housing patterns inside the camp are changing. As the camp develops vertically, new constructions are seen as opportunities for income as the refugee camp, maintaining its exceptionality, develops its own economy and rules. As Salah, a Palestinian I interviewed, and Zahra, the social worker accompanying me during my encounters in Shatila, explained, a person interested in building must seek approval from the owner of the top flat whose permission costs between $2,000-3,000$ US dollars. The roof of the top flat is then turned into the floor of the new house and in this way the construction process continues (Interview with Salah, November 2008).

For Palestinians and non-Palestinians moving to the camp there is also the option of renting a room, renting an entire flat or buying a property. As a member of the Popular Committee of Shatila suggested, although officially these kinds of transactions are not allowed in the camp as refugees do not own the land on which the camp was established, these are to be seen as the development of informal and more flexible economies that allow the population of the camp to make some profit and the newcomers to find a cheaper accommodation (Interview with member of the Popular Committee, December 2008). Salah, in fact, told me that when his father moved to the camp in the 1970s he could not afford to buy an entire flat. So he bought one big room only and rented the rest of the house. Today, he and his family own the entire five-storey building in which they live. To increase their income, he told me, "We are letting the ground floor. The tenant is Syrian" (Interview with Salah, November 2008). Similarly, Doraï (2011), in his research on the Mar Elias refugee camp (Beirut) and the urban dynamics in which the camp is embroiled, explains how Palestinians compensate for the lack of income by building more floors on the top of their roofs and renting to new residents for some $\$ 100-150$ a month. In this way they compete with other more expensive areas of Beirut by 'playing' with the exception. From a space in which the alien is kept far from the national body, the refugee camp turns into a space that welcomes all the categories of people banned from the qualified life of the city. 
Because of their prolonged existence, Beirut's refugee camps seem to have lost their temporary character and to have become more permanent solutions that host refugees as well as other outcasts of the Lebanese system. On the one hand, this permanency is materialised through the utilisation of solid materials such as cement for construction. On the other, the logic of emergency typical of refugee spaces or urban informalities is maintained through construction and vertical expansions which lack planning. Occupying a temporality between temporariness and permanency, Beirut's refugee camps today inhabit 'a "frozen transience", an ongoing, lasting state of temporariness, a duration patched together by moments none of which is lived through as an element of, and a contribution to, perpetuity' (Bauman, 2002: 345). Yet, the high percentage of nonrefugees in Shatila leads us to consider the camp under a different light.

As Nigel Thrift (2006) reminds us, space must be addressed as a process and not as a frozen materiality. It is never static, but is always in constant motion and fluid. Hence, even in the refugee camp understood as the permanent spatialisation of the exception, we witness a development of the camp's physical features with construction in concrete that replaces tents. More importantly, the role and function of the camp may change too. In this sense the camp could be seen as a space in potentiality (Agamben, 1999). It can become a space of abjection in the Agambenian understanding and, therefore, a technology of power aimed at the elimination of the biological threat as happened with the concentration camps in Nazi Germany. But this potential actualisation and transformation into a death factory is only one among other possibilities. The camp can also turn into other more positive and productive spaces (see also Ramadan, 2012; Sanyal, 2011). The ways in which the camp can transform and develop are 'decided' by the sovereign, but, along with him, by the context, circumstances and the people acting on, inhabiting or surrounding it.

As regards the Palestinian refugee camps in Lebanon and in particular the camps that are today part of metropolitan Beirut, I argue that the state of exception is permanent. However, what is excepted changes over time and circumstances as Shatila, like other camps in the city, welcomes different 
kinds of banned and the 'human waste' of the Lebanese system. The camp is, therefore, converted into a space that not only provides cheap solutions for those who cannot afford to live anywhere else in the city, but can also provide a safe haven for those who need to hide and remain in the shadow.

In 1987 the Lebanese government abrogated the Cairo Agreements that allowed the Palestinians to self-administer their spaces. However, Lebanese authorities are still not controlling the camps from within. From a technology of control in the hands of state authorities as it was in the past, the camp has been turned into a technology of invisibility by the same subjects that the sovereign intends to exclude. As the banned exploit the space's exceptional legal status, foreigners can hide from the police and the state in the event that they overstay their visa terms. By the same token, the camp is an exception not only in terms of rights as it hosts those stripped of any protection. The camp itself becomes a finer form of resistance as duties such as taxation are excepted too (Howe, 2005). As the very exception that once produced bare life might be transformed into a form of resistance, the development of informal economies in the camp must be seen as a coping strategy that exploits the exceptionality of this space and the Lebanese authorities' disengagement.

However, this degree of flow and freedom of movement is not allowed in camps outside metropolitan Beirut. While after the civil war checkpoints were a main feature of the refugee spaces and the Lebanese landscape more generally, in the 1990s controls were dramatically reduced in Beirut but never eased in the camps of the south of the country because of their proximity to the border with Israel and the need for more control. So while the camps of the south must be seen as closed spaces (Hanafi, 2008), Beirut's camps are closer to the centre of power and, for this reason, a form of control may be exercised indirectly by such proximity (Interview with Jaber Suleiman, January 2009). However, the Lebanese authorities' disengagement has led to the natural expansion of the camp and the impossibility of distinguishing physically and also symbolically the camp from what lies outside. If state authorities wanted to control the outcasts of the system, it would be difficult to locate security checkpoints nowadays since the refugee population is dispersed also in 
informal gatherings around the camps and in other neighbourhoods such as Said Ghawash, Daouq, Sabra, and Hay El-Gharby all located in the south-west part of the city (Abbas et al., 1997). Indeed, the expansion of the alleged threat, embodied by the Palestinians refugees, the deprived Lebanese and immigrants, would render surveillance of these areas extremely difficult as the exception seems to have 'leaked out' of the camp to also include the 'slum'. To protect economic and political activities, security checks are, therefore, moved from the camps to the entrances of shopping malls and the political and economic heart of the city.

Although Shatila and other camps in metropolitan Beirut are not entirely representative of the situation of the Palestinian spaces in Lebanon, the idea of the campscape captures the paradox that is found in Palestinian camps more broadly in the Middle East. As Puig and Doraï (2012) argue, in the urban areas of Tyre, Beirut and Amman, but also Damascus, the camps are starting to become integrated within the urban texture and dynamics of the city (Ababsa, 2012; Fadhel, 2012). Yet, their legal differentiation from the 'slum' is still clear in the ways in which these spaces are governed. While in Syria and Jordan refugee camps are controlled and administered by the state's authorities, in Lebanon they experience a dramatised exception as they are governed by Palestinian popular and security committees that exercise control only within the camp boundaries (Interview with member of the Popular Committee, December 2008).

The tension between the camp as a solid and exceptional entity and the campscape as a formation that indicates fluidity and connection with its outside is, moreover, supported by the perceptions of the residents. As emerged from the interviews, Palestinian refugees have a clear sense of where camp boundaries lie because of the presence of military checkpoints during the civil war and in its aftermath, and the impossibility to build outside Shatila's boundaries before 1969 when the Lebanese police and intelligence services controlled the camps. And yet, despite this clear sense of where the camp begins and ends, the absence of fences leads to a virtual extension of the space of the camp (Al Husseini, 2012: 48). To the Palestinians the camp (mukhayyam in Arabic) has become a 
way of life. It is wherever there is a significant presence of Palestinian refugees, be they within or beyond Shatila, including the informal settlements surrounding it (Interview with Amina, November 2008).

This fluidity of the camp is also reflected in the living conditions that Shatila shares with the areas and buildings surrounding it. Both the camp and the settlements around it are characterised by overcrowding, lack of adequate services, low-income, low levels of education and general deprivation (UN-HABITAT and UNDP, 2010). Those inhabiting the camp are not worse-off if compared to those living outside legally or squatting. In this way, Shatila lives a tension between its exceptionality as refugee camp and its exclusion from the city centre as part of the 'slum'. While the legal boundaries of the camp matter inasmuch as Palestinians living inside the camp are considered 'legal' while those squatting in adjacent areas risk demolition and eviction every day, these distinctions seem to no longer make sense as law and practice blur into each other.

If, for one moment, we abandon the notion of exception as a legal concept and embrace an exception that might be working on economic and social lines, it becomes apparent that the distinction between the camp and the slum cannot easily be drawn. As the camp welcomes the undesirable and all those excluded from the right to and the space of the city, so does the slum as the logic of exclusion expands indefinitely. As the Armenian camps at the beginning of the last century constituted points of attraction for those in need and search of better opportunities, so does Shatila along with other Palestinian refugee camps in Beirut. While the Lebanese authorities' control and engagement in place produced the closure of the camp in the 1950s and 1960s, their abandonment allows motion and change: motion, as Palestinians began settling outside the camp boundaries especially after the signature of the Cairo Agreements (1969); change, as today the camp has turned into a possibility for those who need to hide from the state's control and who cannot afford to live elsewhere. 
While refugee camps are generally considered 'holes in time and space' as the police contain the refugees within the camp boundaries and prevent them from 'leaking out' and 'spilling over' (Bauman 2000, 2002), Shatila cannot keep its shape any longer and turns into a 'liquid' camp as it expands and allows flows in-and-out. Just like the camp inhabitants leak out, so does the exception as along with the refugees it includes the citizens and other outcasts. The heterogeneous population of the camp meets the diverse residents of the informal settlements as both these spaces host Palestinian refugees, Lebanese rural migrants, and the internally displaced, as well as other Arab and non-Arab people in the shaping of the 'campscape'.

Never has the French word for the term 'slum' been so revealing. As Mustafa Dikeç (2007) explains the term 'banlieue' derives from the word 'ban' or, to recall Agamben's phrase, the inclusive exclusion. As Agier (2011: 45) points out, the banlieue is not a place, but a relation. To be banned stands for that which is included by virtue of its own exclusion. Attached to the centre but abandoned by it, the degraded peripheries of the cities constitute spaces of exclusion and exception as regards care, services and effective planning strategies (Gandy, 2006). As the case of Beirut's informal settlements shows, apart from some exceptions - namely the Elissar project that aims at the rehabilitation of certain areas of south Beirut - the government and local constituencies do not intervene in these areas and they have proven incapable of engaging with it (Fawaz and Peillen, 2002; Harb, 2001, 2003).

If once the wall of the city was to produce bare life, today the pulling down of that barrier marks the pulling down of clear distinctions and the penetration of the banned into the polis. In Beirut, for instance, it is not hard to see poor Shi'ites squatting next to luxurious hotels, awaiting but also resisting eviction (Khalaf, 1998). If the camp was born as the localisation of the exception, the link holding localisation and 'disorder' together has broken down as the supposed-to-be unqualified life has climbed over the fence and somehow entered the space of the city. 
Edkins (2000) posits that Agamben's focus on the reception of migrants and refugees in western countries fails to explore the reasons that lead populations to leave their countries of origins. By analysing the countries of destination and the establishment of spaces of exception to contain the 'alien', Agamben seems to miss the causes of displacement and movement, and the ways in which life has become expendable elsewhere through neoliberal economies and policies. While Edkins speaks of a 'global liberal governance' as the 'contemporary form of biopolitics', Ong (2006) pushes this argument suggesting that neoliberalism has become a technology of governance that unhinges our understanding of concepts such as sovereignty and citizenship. The dichotomy between citizen and non-citizen seems to no longer make sense as '[n]eoliberal governmentality results from the infiltration of market-driven truths and calculations into the domain of politics' (Ong, 2006: 4). While Agamben uses the concept of exception 'as a fundamental principle of sovereign rule predicated on the division between citizen in a juridical order and outsiders stripped of juridical political protections' (2006: 5), Ong argues that in contemporary societies biopolitics may operate in much more complex terrains that include the market factor. As she puts it, 'the infiltration of the market logic into politics conceptually unsettles the notion of citizenship as a legal status rooted in a nationstate, and in stark opposition to a condition of statelessness' (Ong, 2006: 6). We can thus explain how citizenship understood as protection generated through a national belonging can change and turn into a flexible concept that excludes citizens or includes non-citizens according to market and political calculations.

As Dikeç (2007: 24) stresses, neoliberalism must be understood as 'a specific form of political rationality producing new spaces'. In particular, it manifests itself at the urban level as it increases socio-economic inequalities. While urban informalities are understood as spaces hosting the excluded and marginalised, echoing Asef Bayat, AlSayyad (2004: 9) suggests that those inhabiting the ghetto of Chicago or the favelas of Rio do not lack integration into the system. Quite the contrary, they are fully integrated 'but on terms that often cause them to be economically exploited, politically 
repressed, socially stigmatised, and culturally excluded' as a materialisation of the truest and the most intimate meaning of 'ban'.

As bare life in Beirut is not only represented by the Palestinian refugees, economic and social abandonment is applied to other categories of people including Lebanese citizens. The camp is no longer the spatial device that separates the refugee from the citizen. It is no longer a closed and surveilled space typical of disciplinary obsessions. As state authorities withdraw, physical and symbolic boundaries that separate the refugee's bare life from the allegedly qualified life of the citizen blur. As is increasingly the case in other urban centres, we witness 'greater propinquity in social and physical space' and the formation of the threshold where the refugee/immigrant and natives encounter (Wacquant, 1999: 1645). The camp, therefore, escapes the modern illusion of creating homogenised spaces as flows bring heterogeneity to the camp and its outside, giving rise to the campscape.

\section{Conclusions}

Agamben's theory of exception and his position on biopolitics has proved invaluable in understanding the ways in which sovereign power operates and in the ways in which bare life is produced. However, this article has shown how the adoption of a model of analysis exclusively based on law and rights may not exhaust the complexities of biopolitical calculations and bare life production. While there are certainly cases in which the concept of the camp may be fully applied as a clear-cut space of exception, I argue that the camp imagined by Agamben may not be the only one. The camp itself - in its legal understanding and implications - may only partially capture the life that the sovereign casts outside the normal juridical order. Starting from a reflection on the entanglement of Shatila and informal settlements and the presence of non-Palestinians in the camp, the paper has questioned the kind of biopolitics at stake in Lebanon. Secondly, it has questioned the role of Shatila refugee camp today and the spatialities of the exception. 
Abandoning a juridical model that looks at bare life in terms of law and rights, the paper has embraced a Foucauldian understanding of the ways in which power may operate beyond legal domains. In exploring the exception and its spatialities, the paper has focused on flows and openness. It has taken motion, changes and processes as references for an investigation of the exception. This approach explained the presence of other kinds of outcasts within Shatila. As the Palestinians are stripped of their rights, citizenship and protection, the exception 'floats' and is not limited to national belonging distinctions. While the first caesura of the population in Lebanon divides the Lebanese from the Palestinians, other distinctions run along economic and sectarian lines. The latter allows certain Palestinians (the Christians and the upper class) to be included in the normal juridical order and even acquire citizenship. At the same time, they also exclude some Lebanese citizens from the protection and care their state is supposed to grant them.

In this context, structures like refugee camps increasingly become sites that are no longer inhabited by refugees exclusively as the camp welcomes the multiple outcasts of the Lebanese neoliberal and sectarian system. The distinction between the life of the refugee and the qualified political life of the citizen gives way to an increasing propinquity of different kinds of banned who share the same condition and spaces. As both Palestinians and Lebanese (and other outcasts) live in Shatila as well as outside, the exception exceeds the boundaries of the camp to include informal settlements around it. This difficulty in localising the space of exception leads me to consider a new spatial model - the 'campscape' - in which refugee camps and informal settlements represent a new enlarged exception. Although legally the space of exception is represented by the camp only, life, processes and circumstances blur those boundaries. Perhaps an abandonment of spatial disciplinary obsessions has led to the leakage of the exception from the space of the camp to its outside.

This paper demonstrates that political geographers should be ready to embrace new frameworks of spatial analysis. The example of Shatila camp, and other Palestinians camps of the Middle East that are now part of urban textures, shows how the model of the camp provided by Agamben may not 
entirely grasp the complexities of these realities. The refugee camp cannot be uncritically accorded with the space of exception as described by Agamben for three main reasons. Firstly, refugee camps are increasingly becoming permanent solutions to displacement. Rather than seeing refugee camps as responding to the logic of emergency or temporariness, there is an urgency to examine these sites through the lens of 'normality' and as spaces in evolution. An approach that considers the refugee camp for its legal aspect only would inevitably miss new forms of living, coping and being political that may rise in these spaces. Refugee camps may be considered as productive spaces in evolution where new forms of governance can be experimented (Hanafi, 2010). Rather than addressing the camps as spaces of exception, we might examine them as laboratories of the politics at the margins, the 'terrain of habitation, livelihood and politics' where the excluded - be they refugees or other outcasts - may reproduce their new normalcy and negotiate their lives (Roy, 2011: 224).

Secondly, if we consider the exclusion through law, we risk neglecting spaces that deserve equal attention because they are placed outside the 'normal order' in other ways. This paper has problematised the legal prism in approaching the exception. I have argued that the exception does not operate on legal tracks only. As Palestinians are legally excluded from the state's protection, other outcasts are produced along other kinds of political, social and economic exclusions. Although this research has focused on one refugee camp, Shatila, that has been officially recognised and, as such, receives relief and assistance, if we are to investigate lives and spaces that are placed at the margins, perhaps researching 'informal gatherings' (Palestinian and non-Palestinian) would be equally important. The recognition of a formal status (for both refugees and refugee camps) misses those who are left out and who are not even entitled to humanitarian assistance. Future investigations of the Palestinian lives and camps in Lebanon, for example, might consider the condition and the politics of informal gatherings. How are lives and spaces ignored and forgotten by formal politics lived? 
Thirdly, it seems that the refugee camp is not the only spatial referent for refugees. As the UNHCR's (2013) figures show, the spatial order represented by the refugee camp is broken (Sanyal, 2011; 2012). UNHCR, in fact, estimates that only one third of refugees worldwide (those officially considered so) live in refugee camps. Peteet (2011) challenges even more conventional understandings of refugeeness by arguing that the novelty of the refugee condition is the nonrecognition of refugee status and spaces, as in the case of Iraqi refugees in the Middle East or Syrian refugees in Lebanon. Acknowledging that new humanitarian and spatial responses may be changing certainly has methodological implications for future research. We can no longer assume that the 'where' of the refugee is necessarily the camp. In light of this, future studies may enquire into the implications, for refugees, of not living in these spaces. May living outside a refugee camp compromise a refugee's right or desire of return? How are the lives of refugees outside the camp negotiated?

While I do not argue that this kind of evolution in the camp's meaning and function is a model to be uncritically applied to other spaces of exception or the investigation of other refugee camps, I assert that the refugee camp is a space in potentiality. Once the exception is declared there is no single outcome. As understood by Agamben, it can turn into a space of abjection and, therefore, a technology of power aimed at the elimination of the biological threat. But it can also transform into a productive space that welcomes other outcasts or in which the inhabitants exploit and mock the exceptionality of the camp. The ways in which the camp develops are determined by multiple factors. Change can be dictated by the sovereign (Lebanon or other states or suprastate organisations intervening in these sites); the circumstances (urban location, for example); or the agency of people living in the camp and its proximity. These are actors, events and circumstances that cannot always be controlled and guided by the sovereign. 


\section{$\underline{\text { References }}$}

Ababsa, M. (2012). La gestion des quartiers informels en Jordanie. In K. Doraï, \& N. Puig (Eds.), L'urbanité des marges: Migrants et réfugiés dans les villes du Proche-Orient (pp. 87-114). Paris: Téraèdre.

Abbas, M., Shaaban, H., Sirhan, B., \& Hassan, A. (1997). The socio-economic conditions of Palestinians in Lebanon. Journal of Refugee Studies, 10, 378-396.

Agamben, G. (1998). Homo Sacer: Sovereign power and bare life. Stanford: Stanford University.

Agamben, G. (1999). Potentialities: Collected essays in philosophy. Stanford: Stanford University Press.

Agamben, G. (2005). State of exception. Chicago: University of Chicago Press.

Agier, M. (2002). Between war and city: Towards an urban anthropology of refugee camps. Ethnography, 3, 317-341.

Agier, M. (2011). Managing the undesirables: Refugee camps and humanitarian government. Cambridge: Polity Press.

Al Husseini, J. (2012). Les camps de réfugiés palestiniens, soixante ans après. In K. Doraï, \& N. Puig (Eds.), L'urbanité des marges: Migrants et réfugiés dans les villes du Proche-Orient (pp. 39-62). Paris: Téraèdre.

AlSayyad, N. (2004). Urban informality as a 'new' way of life. In A. Roy, \& N. AlSayyad (Eds.), Urban informality: Transnational perspectives from the Middle East, Latin America, and South Asia (pp. 730). Lanham: Lexington Books.

Appadurai, A. (1996). Modernity at large: Cultural dimensions of globalization. Minneapolis: University of Minnesota Press. 
Bauman, Z. (2000). Liquid modernity. Cambridge: Polity Press.

Bauman, Z. (2002). In the lowly nowherevilles of liquid modernity: Comments on and around Agier. Ethnography, 3, 343-349.

Bigo, D. (2007). Detention of foreigners, states of exception, and the social practices of control of the banopticon. In P. K. Rajaram \& C. Grundy-Warr (Eds.), Borderlines: Hidden geographies and politics at territory's edge (pp. 3-33). Minneapolis: University of Minnesota Press.

Clerc-Huybrechts, V. (2008). Les quartiers irreguliers de Beyrouth: Une histoire des enjeux fonciers et urbanistiques dans la banlieu sud. Beirut: IFPO.

Coleman, M. \& Grove, K. (2009). Biopolitics, biopower, and the return of sovereignty. Environment and Planning D: Society and Space, 27, 489-507.

Dikeç, M. (2007). Badlands of the Republic: Space, politics, and urban policy. Oxford: Blackwell.

Diken, B. (2005). City of God. City, 9, 307-320.

Diken, B. \& Laustsen, C. B. (2005). The culture of exception: Sociology facing the camp. London: Routledge.

Doraï, M. K. (2011). Palestinian refugee camps in Lebanon: migration, mobility and the urbanization process. In A. Knudsen \& S. Hanafi (Eds.), Palestinian Refugees: Identity, space and place in the Levant (pp. 67-80). Oxon: Routledge.

Edkins, J. (2000). Sovereign power, zones of indistinctions, and the camp. Alternatives, 25, 3-23.

El-Natour, S. M. (1993). Les Palestiniens du Liban. La situation sociale, economique et juridique. Beirut, Dar Al-Taqqadom Al-Arabi. 
Fadhel, K. (2012). Le camp de Jaramana : Un espace marginal au cœur de l'agglomération damascene. In K. Doraï, \& N. Puig (Eds.), L'urbanité des marges: Migrants et réfugiés dans les villes du Proche-Orient (pp. 115-138). Paris: Téraèdre.

Fawaz, M. and Peillen, I. (2002). Understanding slums: Case studies for the global report 2003 Beirut, Lebanon. UN-HABITAT, available at www.ucl.ac.uk/dpuprojects/Global_Report/cities/beirut.htm (last accessed May 2010).

Foucault, M. (1997). Ethics: Subjectivity and truth. Essential works of Foucault, 1954-1984. Vol. 1, London: Penguin.

Foucault, M. (1998). The will to knowledge: The history of sexuality. Volume 1, London: Penguin.

Foucault, M. (2003). Society must be defended. Lectures at the Collège de France, 1975-76. London: Penguin.

Gandy, M. (2006). Zones of indistinction: Bio-political contestations in the urban arena. Cultural Geographies, 13, 497-516.

Gavin, A. (1998). Heart of Beirut: Making the master plan for the renewal of the central district. In P. G. Rowe \& H. Sarki (Eds.), Projecting Beirut: Episodes in the construction and reconstruction of a modern city (pp. 217-233). Munich: Prestel.

Haddad, S. (2000). The Palestinian Predicament in Lebanon. Middle East Quarterly, 7, 29-40.

Hanafi, S. (2008). Palestinian refugee camps in Lebanon: Laboratories of state-in-making, discipline and Islamist radicalism. In R. Lentin (Ed.), Thinking Palestine (pp: 82-100). London: Zed Books.

Hanafi, S. (2010). Palestinian refugee camps in Lebanon: Laboratories of indocile identity formation. In M. A. Khalidi (Ed.), Manifestations of identity: The lived reality of Palestinian refugees in Lebanon (pp: 45-74). Beirut: Institute for Palestine Studies. 
Harb, M. (2001). Urban governance in post-war Beirut: Resources, negotiations, and contestations in the Elyssar Project. In S. Shami (Ed.), Capital Cities: Ethnographies of urban governance in the Middle East (pp. 111-133). Toronto: Toronto University Press.

Harb, M. (2003). Al-Dahiye de Beyrouth: Parcours d'une stigmatisation urbaine, consolidation d'un territoire politique. Genèses, 51, 70-91.

Howe, M. (2005). Palestinians in Lebanon. Middle East Policy, 12, 145-155.

Khalaf, S. (1998). Contested space and the forging of new cultural identities. In P. Rowe \& H. Sarkis (Eds.), Projecting Beirut: Episodes in the construction and reconstruction of a modern city (pp. 140164). Munich: Prestel.

Lui, R. (2002). Governing refugees 1919-1945. Borderlands,1.

Maktabi, R. (1999). The Lebanese census of 1932 revisited: Who are the Lebanese?. British Journal of Middle Eastern Studies, 26, 219-241.

Minca, C. (2007). Agamben's geographies of modernity. Political Geography, 26, 78-97.

Ong, A. (2006). Neoliberalism as exception: Mutations in citizenship and sovereignty. Durham: Duke University Press.

Perera, S. (2002). What is a camp...?. Borderlands, 1.

Peteet, J. (2005). Landscapes of hope and despair: Palestinian refugee camps. Philadelphia: University of Pennsylvania Press.

Peteet, J. (2011). Cartographic violence, displacement and refugee camps: Palestine and Iraq. In A. Knudsen \& S. Hanafi (Eds.), Palestinian Refugees: Identity, space and place in the Levant (pp. 13-28). Oxon: Routledge. 
Puig, N. \& Doraï, K. (2012). Insertions urbaines et espaces relationnels des migrants et réfugiés au Proche-Orient. In K. Doraï, \& N. Puig (Eds.), L'urbanité des marges: Migrants et réfugiés dans les villes du Proche-Orient (pp. 11-25). Paris: Téraèdre

Rajaram, P. K. (2007). Locating political space through time: Asylum and excision in Australia. In P. K. Rajaram \& C. Grundy-Warr (Eds.), Borderlines: Hidden geographies and politics at territory's edge (pp. 263-283). Minneapolis: University of Minnesota Press.

Rajaram, P. K. \& Grundy-Warr, C. (2004). The irregular migrant as homo sacer: Migration and detention in Australia. International Migration, 42, 33-62.

Ramadan, A. (2012). Spatialising the refugee camp. Transactions of the Institute of British Geographers, 38, 65-77.

Roy, A. (2011). Slumdog Cities: Rethinking Subaltern Urbanism. International Journal of Urban and Regional Research, 35.2, 223-238.

Salam, A. (1998). The role of government in shaping the built environment. In P. G. Rowe \& H. Sarkis (Eds.), Projecting Beirut: Episodes in the construction and reconstruction of a modern city (pp. 122133). Munich: Prestel.

Salibi, K. (1976). Crossroads to civil war. New York: Caravan.

Sanyal, R. (2011). Squatting in Camps: Building and Insurgency in Spaces of Refuge. Urban Studies, 48, 877-890.

Sanyal, R. (2012). Refugees and the City: An Urban Discussion. Geography Compass, 6, 633-644.

Sayigh, R. (1994). Too many enemies: The Palestinian experience in Lebanon. London: Zed Books.

Schmitt, C. (2003). The Nomos of the Earth in the International Law of the Jus Publicum Europaeum, New York: Telos Press Publishing. 
Thrift, N. (2006). Space. Theory, Culture \& Society, 23, 139-146.

Traboulsi, F. (2007). A history of modern Lebanon. London: Pluto Press.

UNHCR (2013). UNHCR Statistical Yearbook 2011, available at http://www.unhcr.org/516285b89.html (last accessed May 2013).

UN-Habitat and UNDP (2010). Investigating grey areas: Access to basic urban services in the adjacent areas of Palestinian refugee camps in Lebanon, UNDP/UN-Habitat, Beirut, available at http://www.unhabitat.org/pmss/listltemDetails.aspx?publicationID=3080 (last accessed November 2011).

UNRWA (2014a). Who we are, available at http://www.unrwa.org/who-we-are (last accessed June 2014).

UNRWA (2014b). UNRWA in figures as of 1 July 2013, available at http://www.unrwa.org/sites/default/files/unrwa_in_figures_new2014_10nov2014.pdf (last accessed June 2014).

Wacquant, L. (1999). Urban marginality in the coming millennium. Urban Studies, 36, 1639-1647.

\section{List of interviews cited}

(Please note that these are not real names as anonymity has been guaranteed).

Ahmad, Shatila, December 2008. Interview conducted in Arabic.

Amina, Sabra, November 2008. Interview conducted in Arabic.

Fadi, Sabra, December 2008. Interview conducted in Arabic.

Jaber Suleiman (Palestinian scholar), Mar Elias, January 2009. Interview conducted in English.

Member of Popular Committee of Shatila, December 2008. Interview conducted in Arabic. 
Salah, Shatila, November 2008. Interview conducted in Arabic. 